\title{
Programy wspomagające uruchamianie mikroprocesorowych systemów sterowania w pojazdach szynowych
}

\begin{abstract}
W artykule opisano programy „DIAGNOSTYKA” oraz „,WYKRESY” wykorzystywane przy wdrażaniu mikroprocesorowych systemów sterowania w pojazdach szynowych. Pierwszy z nich stuży do akwizycji danych diagnostycznych z systemu sterowania natomiast drugi do prezentacji tych danych $w$ formie wykresów, które można zachować w postaci plików graficznych.

Artykut powstat $w$ wyniku prac wykonanych m.in. $w$ ramach projektu badawczego $n r 4 T 12 D 05430$ pt. "Zastosowanie satelitarnego systemu akwizycji danych do poligonowych badań spalinowych pojazdów szynowych” dofinansowanego przez Ministersto Nauki i Szkolnictwa Wyższego.
\end{abstract}

\section{Wstęp}

Nowoczesne pojazdy szynowe wyposażane są w podzespoły na coraz wyższym poziomie technicznym, sterowane w technice mikroprocesorowej. Również IPS „TABOR” ma swój wkład w tej dziedzinie, projektując i wdrażając następujące systemy sterowania:

1. sterowanie układem ogrzewania pociagu na zmodernizowanej lokomotywie spalinowej SP42 (SU42 serii 500),

2. sterowanie i diagnostyka układu pneumatycznego na zmodernizowanej lokomotywie elektrycznej ET22,

3. sterowanie i diagnostyka układu pneumatycznego oraz układ przeciwpoślizgowy na zmodernizowanej lokomotywie spalinowej ST44,

4. sterowanie globalną współpracą (w ramach całej jednostki) hamulca ED z hamulcem EP na ezt $15 \mathrm{WE}$ i $16 \mathrm{WE}$,

5. sterowanie nagrzewnicą tramwajową.

Wymienione systemy sterowania oparte są na sterownikach programowalnych, zwanych również sterownikami mikroprocesorowymi lub sterownikami PLC (ang. Programmable Logic Controllers). W projektach wykorzystano sterowniki firm: Siemens $A G$ (Niemcy), PEP Modular Computers - obecnie Kontron (USA) i Selectron Systems AG (Szwajcaria).

Podczas uruchamiania systemów sterowania w pojazdach szynowych konieczne jest zbadanie poprawności przyjętych algorytmów sterowania oraz działania oprogramowania zaimplementowanego $\mathrm{w}$ sterownikach na podstawie tych algorytmów.

Ocenę poprawności algorytmów i oprogramowania umożliwia analiza sygnałów sterujących, generowanych przez sterownik na podstawie doprowadzonych do niego sygnałów wejściowych. W tym celu sterownik mikroprocesorowy przesyła co $100 \mathrm{~ms}$ do komputera serwisowego ramkę danych diagnostycznych.

Do przesyłania danych wybrano interfejs (sprzęg, łącze) szeregowy RS 232 (ang. Recommended Standard) z uwagi na to, że port szeregowy jest standardowym wyposażeniem zarówno komputerów (oznaczany jako „COM”), jak też sterowników PLC. W przypadku sterowników jest on wykorzystywany do ich programowania, ale umożliwia również transmisję danych podczas normalnej pracy sterownika.

RS 232C jest wersją interfejsu szeregowego wprowadzoną w 1969 roku i oficjalnie podniesioną do rangi standardu w roku 1986. RS 232C jest powszechnie stosowanym i akceptowanym standardem dla szeregowej (bit po bicie) wymiany danych cyfrowych pomiędzy urządzeniem DTE (ang. Data Terminal Equipment) - obecnie utożsamianym z komputerem, a DCE (ang. Data Communication Equipment) obecnie utożsamianym $\mathrm{z}$ urządzeniem zewnętrznym (pierwotnie z modemem). Definiuje on w sposób jednoznaczny parametry elektryczne, mechaniczne i logiczne łącza szeregowego [1].

Pod pojęciem komputera serwisowego rozumiany jest komputer przenośny wyposażony $\mathrm{w}$ port szeregowy $\mathrm{z}$ zainstalowanym oprogramowaniem narzędziowym do programowania sterowników (Siemens: Step7, PEP Modular Computers: ISaGRAF, Selectron: CAP1131).

Dane diagnostyczne przesyłane przez sterownik są odbierane, prezentowane i gromadzone na twardym dysku komputera za pośrednictwem programu „DIAGNOSTYKA”. Dla każdego uruchamianego systemu sterowania tworzona jest dedykowana do współpracy z nim kolejna wersja programu „DIAGNOSTYKA". Poszczególne wersje różnią się od siebie obsługiwaną ramką danych (ilością i rodzajem przesyłanych danych), wysyłaną przez sterownik PLC.

Archiwizacja danych diagnostycznych polega na zapisywaniu kolejnych ramek przesyłanych przez sterownik jako kolejnych wierszy pliku tekstowego. W wyniku analizy wykresów stworzonych na podstawie tych plików można dokładnie prześledzić działanie sterowanego układu, a tym samym wychwycić ewentualne błędy przyjętych algorytmów sterowania, błędy oprogramowania sterownika, ale także niewłaściwe działanie samego układu. 
Program „WYKRESY” służy do tworzenia przebiegów czasowych wybranych danych diagnostycznych na podstawie plików tekstowych generowanych przez program „DIAGNOSTYKA” oraz do zachowania otrzymanych wykresów w postaci plików graficznych. Program „WYKRESY” jest uniwersalny, tzn. obsługuje wszystkie pliki tworzone przez program „DIAGNOSTYKA” niezależnie od jego wersji, a co za tym idzie, niezależnie od rozmiaru zapisanych w nich ramek danych.

\section{Sterowniki programowalne}

Sterowniki programowalne $(P L C)$ są komputerami przemysłowymi, które pod kontrolą systemu operacyjnego czasu rzeczywistego [2]:

- zbierają pomiary za pomocą modułów wejściowych z cyfrowych i analogowych czujników oraz urządzeń pomiarowych

- korzystając z uzyskanych danych o sterowanym procesie lub maszynie, wykonują programy użytkownika, zawierające zakodowane algorytmy sterowania i przetwarzania danych

- generują sygnały sterujące odpowiednie do wyników obliczeń tych programów i przekazują je przez moduły wyjściowe do elementów i urządzeń wykonawczych

a ponadto dają możliwość:

- transmitowania danych za pomocą modułów i łączy komunikacyjnych

- realizacji funkcji diagnostyki programowej i sprzętowej.
Schemat ideowy sterownika PLC przedstawiono na rysunku 1

Podstawowymi elementami sterownika są [2]:

1. moduły wejściowe, za pomocą których są wprowadzane do sterownika sygnały z czujników, zadajników oraz urządzeń pomiarowych w obiekcie - sygnały te stanowią wejścia sterownika,

2. jednostka centralna, która na podstawie przechowywanego w pamięci programu oraz odczytanych wejść sterownika oblicza wartości sterowań i zapisuje je do pamięci wyjść (w sterownikach moduł jednostki centralnej $C P U$ (ang. Central Processing Unit) oznacza nie tylko mikroprocesor, lecz także pamięć programu użytkownika oraz pamięć danych),

3. moduły wyjściowe, które przekazują obliczone sygnały sterujące do elementów i urządzeń wykonawczych - sygnały te stanowią wyjścia sterownika.

Głównym zadaniem sterownika jest generowanie sygnałów sterujących w odpowiedzi na zmiany sygnałów wejściowych, zgodnie z przyjętym algorytmem sterowania lub regulacji. Reakcja ta zależy od wyników operacji arytmetyczno-logicznych wykonanych dla aktualnych wartości wejść sterownika, jego zmiennych wewnętrznych oraz od zaprogramowanych warunków czasowych. Może ona także zależeć od operacji wykonanych na danych transmitowanych $\mathrm{w}$ sieciach łączących wiele elementów pomiarowych, sterowników, regulatorów czy komputerów [2].

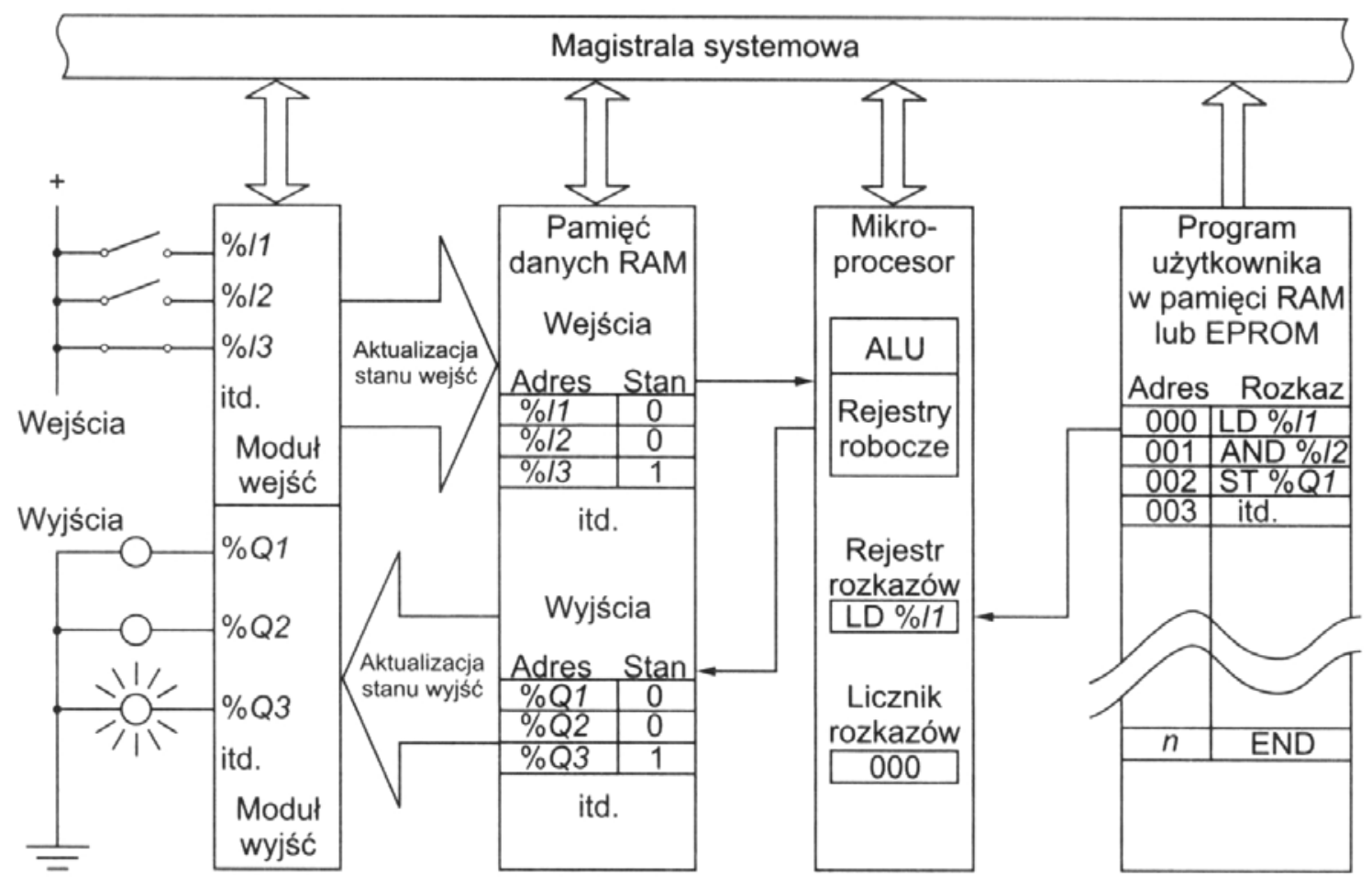

Rys. 1. Schemat ideowy sterownika programowalnego PLC [2] 
Sterownik pracuje w tzw. czasie rzeczywistym (ang. Real Time). Oznacza to, że reakcja sterownika $\mathrm{w}$ postaci obliczonego sterowania $\mathrm{w}$ odpowiedzi na zmianę wejść musi wystąpić w określonym czasie, akceptowalnym z punktu widzenia wymagań stawianych temu sterowaniu. Uzyskuje się to na drodze cyklicznego odczytu stanu sygnałów wejściowych, wykonywaniu programu użytkownika i aktualizacji sygnałów wyjściowych [2].

Sterownik pracuje w cyklu programowym (ang. Program Sweep), w którym:

- w fazie aktualizacji stanu wejść następuje przepisanie wartości wejść z modułów wejściowych do odpowiadających im obszarów w pamięci danych sterownika (na rys. 1 oznaczonych jako „\%In”, gdzie n jest numerem wejścia)

- w fazie wykonania programu realizowany jest jeden przebieg programu użytkownika - kolejne instrukcje programu przekazywane są $\mathrm{z}$ pamięci programu do mikroprocesora, który je dekoduje, wykonuje odpowiednie działania i zapisuje wynik obliczeń w pamięci danych

- w fazie aktualizacji wyjść następuje przepisanie obliczonych wartości wyjść (na rys. 1 oznaczonych jako „\%Qn”, gdzie n jest numerem wyjścia) z odpowiedniego obszaru danych do modułów wyjściowych, które generują sygnały sterujące.

3. Realizacja połączenia pomiędzy sterownikiem mikroprocesorowym a komputerem serwisowym za pośrednictwem interfejsu RS232

\subsection{Realizacja połączenia od strony sprzętowej}

Sterownik mikroprocesorowy łączy się $\mathrm{z}$ komputerem serwisowym (rys. 2) za pośrednictwem przewodu 3-żyłowego, zakończonego od strony komputera wtyczką złącza DB-9 z wyprowadzeniami żeńskimi (gdyż komputer wyposażony jest w gniazdo złącza DB-9 z wyprowadzeniami męskimi) a od strony sterownika 3-polową listwą zaciskowa, przy wykorzystaniu jedynie trzech linii interfejsu RS232:

- RxD, RXD (ang. Received Data): dane odbierane

- TxD, TXD (ang. Transmitted Data): dane wysyłane

- GND (ang. Ground), COM (ang. Common): masa sygnałowa.
W publikacji oznaczono RxD, TxD, GND jako wyprowadzenia portu szeregowego w komputerze serwisowym, natomiast RXD, TXD, COM jako wyprowadzenia w sterowniku PLC.

\subsection{Realizacja połączenia od strony programowej}

Aby nawiązać transmisję pomiędzy sterownikiem PLC a komputerem serwisowym należy:

- ustalić strukturę przesyłanej ramki danych diagnostycznych oraz parametry transmisji

- oprogramować sterownik pod kątem nadawania danych diagnostycznych po łączu szeregowym

- wyposażyć komputer serwisowy w program „DIAGNOSTYKA” obsługujący jego port szeregowy, który realizuje zadania odbioru, wizualizacji i archiwizacji danych diagnostycznych.

\subsubsection{Struktura ramki danych diagnostycznych}

Dane diagnostyczne, zawierają następujące informacje:

- stan wejściowych sygnałów cyfrowych

- wartości wejściowych sygnałów analogowych i częstotliwościowych

- dane wymieniane z innymi sterownikami (np. ze sterownikiem głównym pojazdu)

- wartości niektórych zmiennych obliczanych przez program sterownika w celu odpowiedniego wysterowania wyjść

- stan wyjściowych sygnałów sterujących.

Sterownik w każdym cyklu programowym (co $100 \mathrm{~ms}$ ) konwertuje powyższe dane diagnostyczne do postaci znaków typu CHAR. Dane te są kodowane wg kodu ASCII z wykorzystaniem następującego klucza:

- 8 BIN $\rightarrow 1$ znak CHAR (np. stan 8 wejść lub wyjść cyfrowych)

- 1 DEC $\rightarrow 1$ lub 2 znaki CHAR (w zależności od zakresu wartości i wymaganej precyzji, np. pomiar ciśnienia z zakresu od $0 \mathrm{kPa}$ do 1000 $\mathrm{kPa} \mathrm{z}$ rozdzielczością $1 \mathrm{kPa}$ ).

Ramka danych diagnostycznych wysyłana przez sterownik jest więc ciagiem $\mathrm{n}$ znaków typu CHAR (rys. 3) o długości zależnej od ilości i od rodzaju przesyłanych danych. Dlatego też dla każdego projektu powstaje kolejna wersja programu „DIAGNOSTYKA", który dekoduje odebraną ramkę na wartości konkretnych danych diagnostycznych.

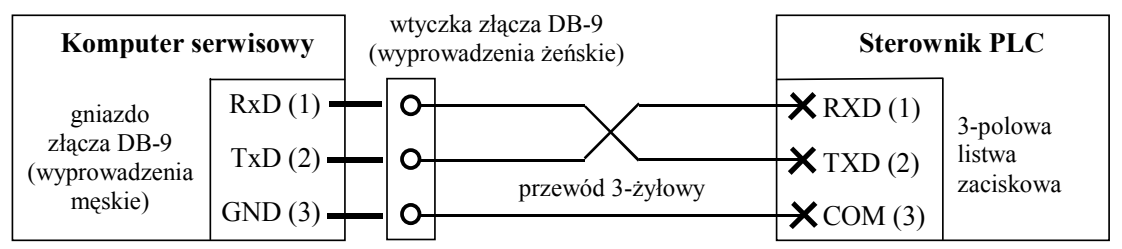

Rys. 2. Schemat połączenia sterownika mikroprocesorowego i komputera serwisowego za pośrednictwem interfejsu RS232 


\begin{tabular}{|c|c|c|c|c|c|c|c|}
\hline znak 1 & znak 2 & & znak (n-4) & $\mathrm{k}(\mathrm{n}-3$ & ak (n-2 & lak (n-1) & znak n \\
\hline Licznik & DANE & . & DANE & 'E' & 'N' & 'D' & LF \\
\hline
\end{tabular}

Rys. 3. Struktura ramki danych diagnostycznych

Struktura ramki danych diagnostycznych jest następująca:

- znak 1 - zmienna Licznik, której wartość zmienia się w zakresie od 1 do 100 kontrola poprawności transmisji

- znak 2 .. znak (n-4) - zakodowane dane diagnostyczne

- znak (n-3) - wartość stała 'E' (znak ASCII: \#69) - kontrola poprawności transmisji

- znak (n-2) - wartość stała 'N' (znak ASCII: \#78) - kontrola poprawności transmisji

- znak (n-1) - wartość stała 'D' (znak ASCII: \#68) - kontrola poprawności transmisji

- znak (n) - wartość stała LF (znak ASCII: \#10) - kontrola poprawności transmisji.

\subsubsection{Parametry transmisji}

Aby nawiązać komunikację pomiędzy sterownikiem a komputerem serwisowym należy odpowiednio skonfigurować ich porty szeregowe, poprzez ustalenie:

- prędkości transmisji

- sposobu kontroli parzystości (wykorzystania bitu parzystości), dostępne opcje: (0) NO PARITY - brak kontroli parzystości, (1) ODD PARITY - kontrola nieparzystości ilość jedynek w polu danych uzupełniana jest za pośrednictwem bitu parzystości do liczby nieparzystej, (2) EVEN PARITY - kontrola parzystości - ilość jedynek w polu danych uzupełniana jest za pośrednictwem bitu parzystości do liczby parzystej

- ilości bitów danych, dostęne opcje: 8 (odpowiada 1 Bajtowi danych), 7, 6, 5

- ilości bitów stopu, dostępne opcje: 1,2

- protokołu transmisji, dostępne opcje: (0) NONE - bez protokołu, (1) XON/XOFF - aktywny protokół programowy XON/XOFF (możliwy tylko dla transmisji realizowanej w trybie FULL DUPLEX), (2) RTS/CTS - aktywny protokół sprzętowy RTS/CTS FLOW CONTROL (możliwy tylko dla transmisji realizowanej z wykorzystaniem linii sterujących RTS i CTS interfejsu RS232).

Przyjęto następujące parametry transmisji pomiędzy sterownikiem a komputerem serwisowym:

- prędkość transmisji: 38400 bitów / s

- $\quad$ kontrola parzystości: NO PARITY

- protokół transmisji: NONE

- ramka pojedynczego znaku (rys. 4) składa się z 11 bitów: 1 bit startu (START), 8 bitów danych (D1 .. D8) reprezentujących przesyłany znak CHAR, 1 bit parzystości, 1 bit stopu.

bit 1 bit 2 bit 3 bit 4 bit 5 bit 6 bit 7 bit 8 bit 9 bit 10 bit 11

\begin{tabular}{|l|l|l|l|l|l|l|l|l|l|l|}
\hline START & D1 & D2 & D3 & D4 & D5 & D6 & D7 & D8 & PARITY & STOP \\
\hline
\end{tabular}

Rys. 4. Struktura ramki pojedynczego znaku

\section{Obsługa i dzialanie programu „DIAGNO- STYKA"}

Program „DIAGNOSTYKA” został zaimplementowany w środowisku Borland Delphi 7. Okno główne programu pokazano na rysunku 5. Jego obsługa jest intuicyjna a zastosowane zabezpieczenia uniemożliwiają wykonanie przez program lub użytkownika czynności nieprawidłowych.

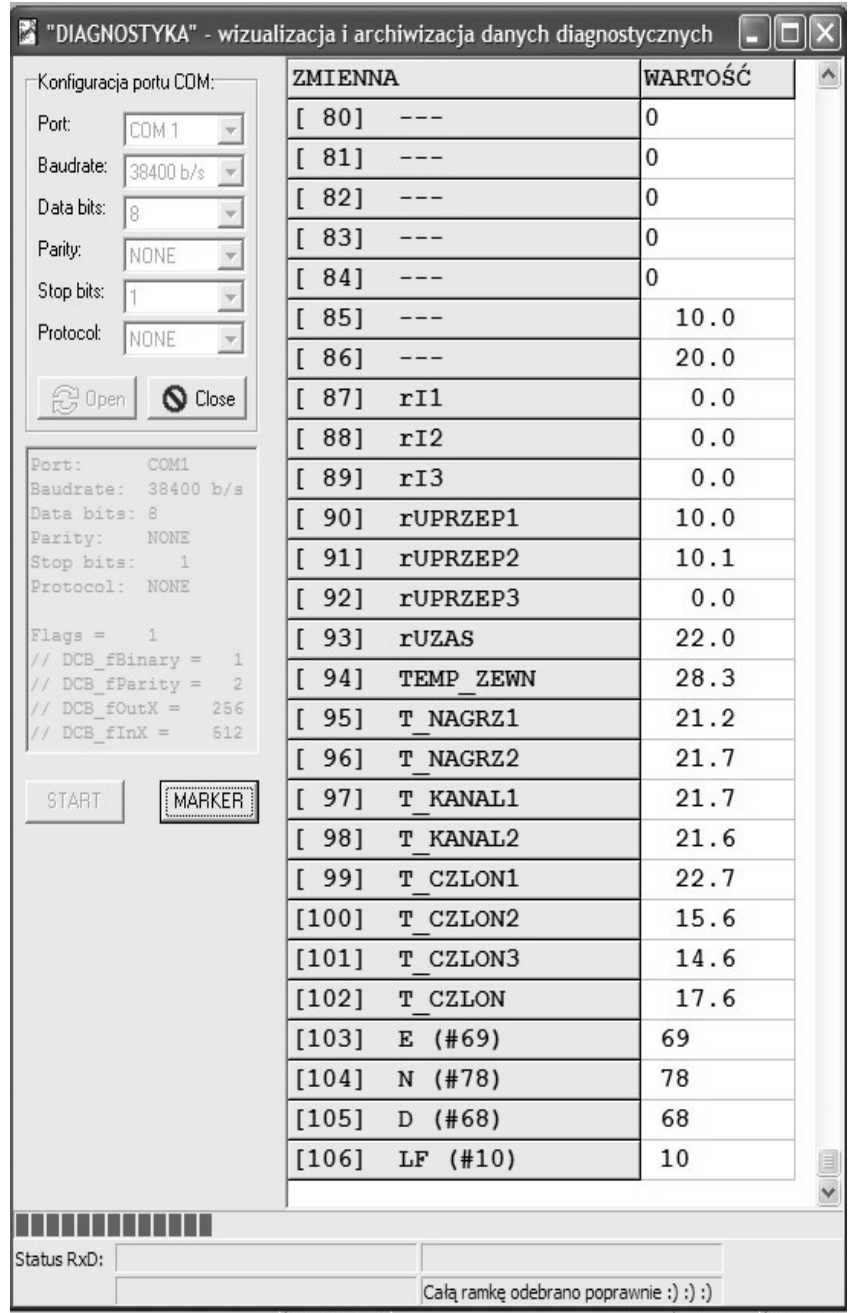

Rys. 5. Okno główne programu „DIAGNOSTYKA” podczas gromadzenia danych ze sterownika nagrzewnicy tramwajowej 
Zadania realizowane przez program „DIAGNOSTYKA":

1. obsługa portu RS232 komputera serwisowego:

a. konfiguracja portu szeregowego:

1. wybór portu (Port): od COM 1 do COM 12

2. wybór prędkości transmisji (Baudrate) [bitów / s]: 38400, 19200, 9600, 4800, 2400, 1200, 600, 300,

3. wybór ilości bitów danych (Data bits): 8, 7,

4. wybór rodzaju kontroli parzystości (Parity): NONE, ODD, EVEN,

5. wybór ilości bitów stopu (Stop bits): 1, 2,

6. wybór protokołu transmisji (Protocol): $\mathrm{XON} / \mathrm{XOFF}$,

b. inicjacja portu zgodnie $\mathrm{z}$ wybraną konfiguracja,

c. możliwość zmiany konfiguracji portu $\mathrm{w}$ trakcie działania programu,

d. zamknięcie portu podczas zamykania programu.

2. odbiór ramki danych diagnostycznych z portu szeregowego komputera i jej dekodowanie $z$ ciągu znaków CHAR na wartości poszczególnych danych diagnostycznych,

3. wizualizacja danych diagnostycznych odbieranych ze sterownika,

4. archiwizacja danych diagnostycznych odbieranych ze sterownika:

a. zapis odebranych danych diagnostycznych do pliku tekstowego o formacie nazwy gwarantującym jego jednoznaczną identyfikację (punkt 4.2),

b. wstawianie do powyższego pliku znacznika postaci '9999999' zamiast indeksu odebranych ramek (punkt 4.8) w celu oznaczenia danych wymagających dokładniejszej analizy.

\subsection{Konfiguracja portu}

Po uruchomieniu programu należy skonfigurować wybrany port szeregowy wybierając odpowiednie opcje za pomocą list wyboru. Próba otwarcia portu następuje po naciśnięciu przycisku „Open”. W przypadku, gdy komputer nie posiada portu o wybranej nazwie lub gdy wybrany port jest już używany przez inny program, pojawia się odpowiedni komunikat informujacy o tym fakcie.

Po poprawnej konfiguracji portu przycisk „Open” oraz listy wyboru opcji konfiguracyjnych portu stają się nieaktywne, przyciski "Close” i „START" stają się aktywne, a w polu poniżej przycisków „Open” i „Close” pojawiają się parametry konfiguracyjne otwartego portu.

\subsection{Uruchomienie odczytu danych diagnostycz- nych}

Aby uruchomić odczyt danych z portu szeregowego należy nacisnąć przycisk „START”. Folderem domyślnym, w którym tworzony jest plik tekstowy generowany przez program, jest folder, w którym znajduje się plik wykonywalny programu Diagnostyka.exe.

Nazwa wynikowego pliku tekstowego składa się $\mathrm{z}$ przedrostka identyfikującego pojazd lub sterownik oraz daty i czasu pobieranych z systemu operacyjnego komputera w chwili tworzenia pliku. Przyjęty format nazwy pliku gwarantuje jego jednoznaczna identyfikację oraz to, że żaden plik z danymi nie zostanie omyłkowo nadpisany. W przypadku sterownika wdrożonego na lokomotywie ST44 przyjęto następujący format nazwy pliku:

„NumerLokomotywy NumerKabiny Data Czas .dia”, gdzie:

Data: YYr_MM_DD (Y - rok, M - miesiąc, $\mathrm{D}$ - dzień),

Czas: hh_mm_ss $(\mathrm{h}-$ godzina, $\mathrm{m}$ - minuta, $\mathrm{s}$ - sekunda),

np.: ,3001 kab2 05r_08_26 08_29_48.dia”.

Po utworzeniu pliku wynikowego program zaczyna odczytywać dane $\mathrm{z}$ linii $\mathrm{RxD}$ wybranego portu szeregowego, przycisk „START” staje się nieaktywny, przycisk „MARKER” staje się aktywny.

\subsection{Status linii RxD}

W dolnej części okna programu wyświetlana jest informacja o stanie linii RxD (odbiór danych). Możliwe są cztery przypadki:

1. na linii $\mathrm{RxD}$ nie ma żadnych danych do odebrania lub skonfigurowano niewłaściwy port,

2. nie odebrano jeszcze całej ramki danych,

3. odebrano odpowiednią ilość znaków, ale ciag ten nie jest zakończony sekwencją: 'E', 'N', 'D', LF,

4. poprawnie odebrano całą ramkę danych.

\subsection{Wizualizacja $i$ archiwizacja danych diagno- stycznych}

W przypadku poprawnego odebrania całej ramki danych program przeprowadza operację jej dekodowania z ciągu znaków CHAR na wartości poszczególnych danych diagnostycznych. Dane te są wyświetlane w kolejnych wierszach tabeli oraz zapisywane do wynikowego pliku tekstowego. Podgląd kolejnych wierszy tabeli umożliwia pasek przewijania umieszczony po prawej stronie tabeli z danymi diagnostycznymi. 


\subsection{Wstawianie znacznika}

Istnieje możliwość wstawienia do pliku wynikowego, za pomocą przycisku „MARKER”, znacznika postaci '9999999' zamiast indeksu odebranych ramek w celu oznaczenia danych wymagajacych dokładniejszej analizy.

\subsection{Zmiana konfiguracji portu}

$\mathrm{W}$ trakcie działania programu istnieje możliwość zmiany konfiguracji portu. W tym celu należy zamknąć otwarty port przyciskiem „Close” a następnie dokonać ponownej konfiguracji wybranego portu.

\subsection{Zakończenie działania programu}

W celu zakończenia działania programu należy w pierwszej kolejności zamknąć otwarty port przyciskiem „Close” a następnie zamknąć okno programu.

\subsection{Struktura pliku tekstowego generowanego przez program „DIAGNOSTYKA”}

Na rysunku 6 zamieszczono przykładowo fragment wynikowego pliku tekstowego wygenerowanego przez program „DIAGNOSTYKA” podczas uruchamiania systemu sterowania nagrzewnicą tramwajowa. Fragment ten zawiera dwie ramki danych odebrane ze sterownika.

Plik tekstowy generowany przez program „DIAGNOSTYKA" zawiera następujące informacje:

- wiersze 1 do 8: sygnatura pliku

- wiersz 11: identyfikator pojazdu lub sterownika

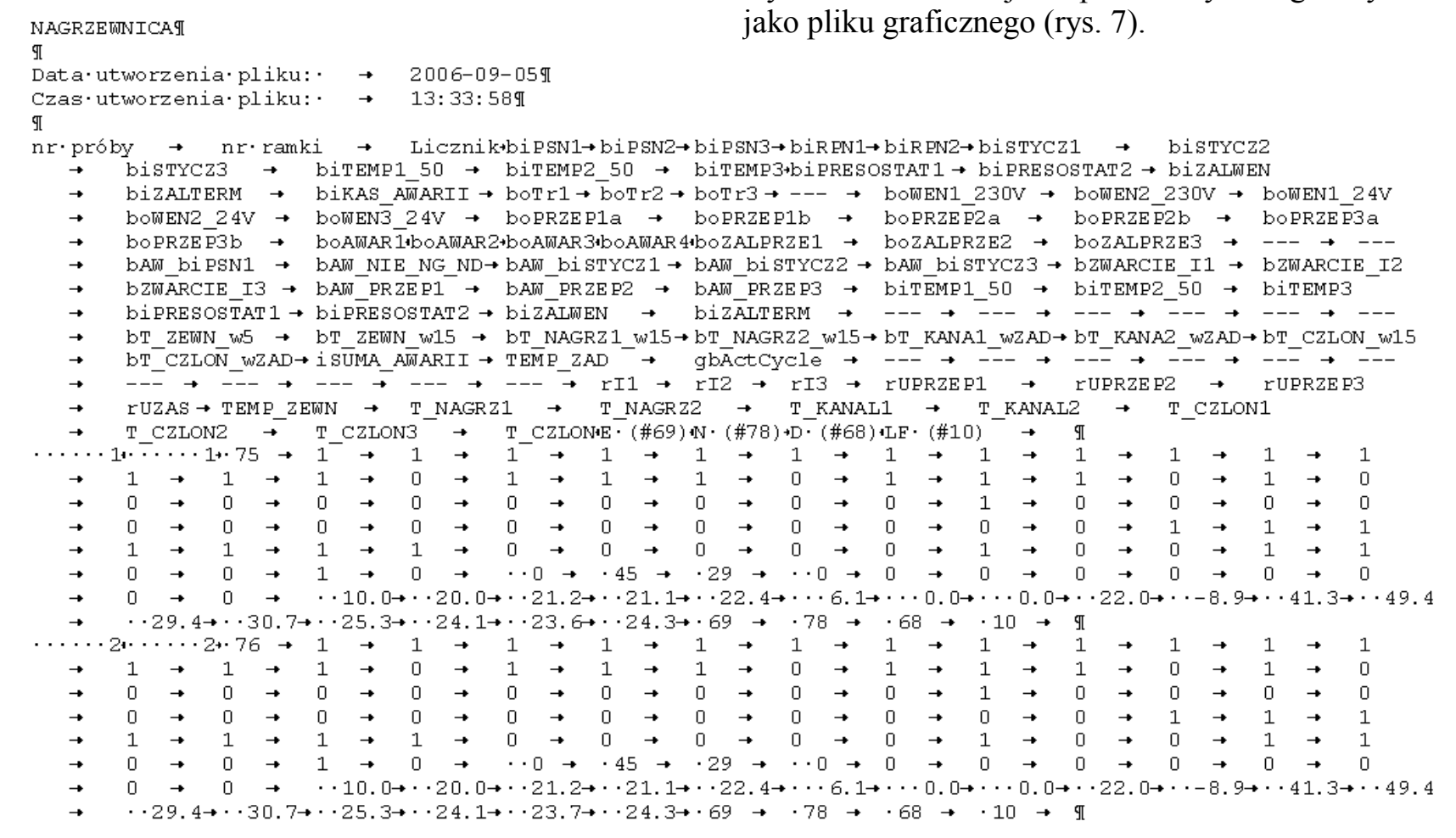

Rys. 6. Fragment pliku tekstowego wygenerowanego przez program „DIAGNOSTYKA” podczas gromadzenia danych

Rys. 6. Fragment pliku tekstowego wygenerowanego przez program „DIAGNOST
ze sterownika nagrzewnicy tramwajowej
- wiersz 13: data utworzenia pliku

- wiersz 14: czas utworzenia pliku

- wiersz 16: opis danych diagnostycznych zapisanych w poszczególnych kolumnach

- wiersze od 17:

○ kolumna 1: indeks prób odebrania ramek

- kolumna 2: indeks odebranych ramek

- kolumny następne: dane diagnostyczne.

\section{Obsługa i dzialanie programu "WYKRESY"}

Program „WYKRESY” został zaimplementowany w środowisku Borland Delphi 7. Jego obsługa jest intuicyjna a zastosowane zabezpieczenia uniemożliwiają wykonanie przez program lub użytkownika czynności nieprawidłowych.

Podstawowym zadaniem realizowanym przez program „WYKRESY” jest generowanie przebiegów czasowych danych diagnostycznych zapisanych w plikach tekstowych uzyskanych w wyniku działania programu „DIAGNOSTYKA”. Program „WYKRESY" pozwala na stworzenie do 20 przebiegów danych diagnostycznych (serii) na jednym wykresie. Umożliwia zmianę atrybutów narysowanego wykresu, takich jak: kolor, grubość oraz rodzaj linii poszczególnych serii, widoczność danej serii oraz minimum, maksimum i podziałkę obu osi. Otrzymany wykres można zapisać do pliku formatu WMF (ang. Windows Metafile) lub EMF (ang. Enhanced Metafile).

Okno główne programu składa się z części, w której prezentowany jest wykres oraz z części, w której zgromadzone są: przycisk „Otwórz plik (*.dia)”, elementy umożliwiające konfigurację otrzymanego wykresu oraz sekcja zapisu otrzymanego wykresu jako pliku graficznego (rys. 7). 


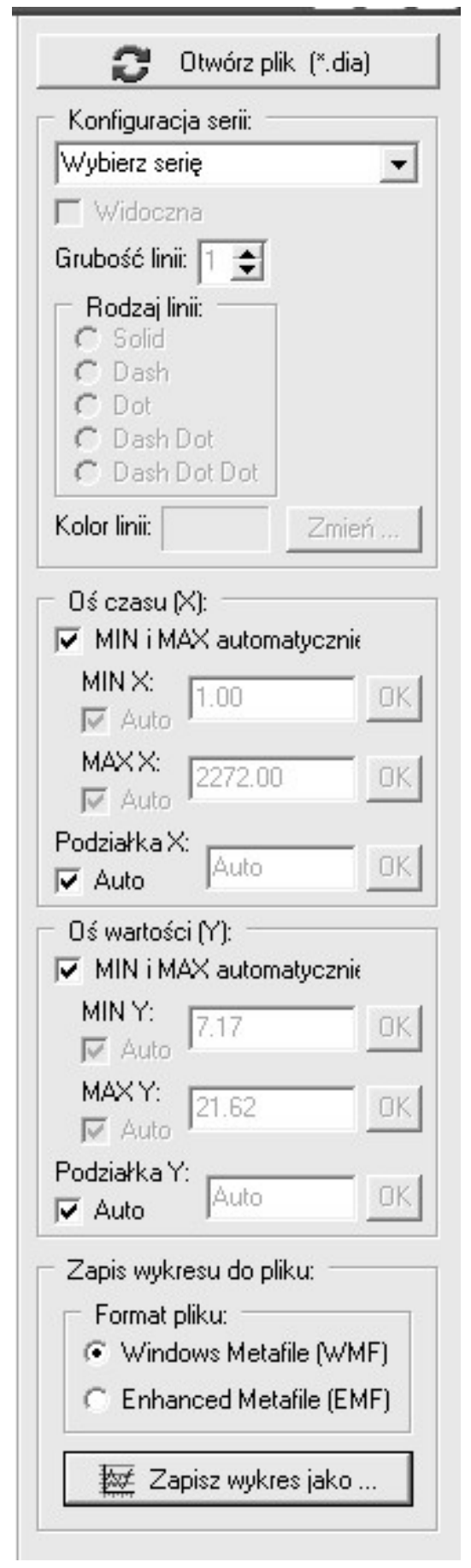

Rys. 7. Część sterująca okna głównego programu „WYKRESY”

\subsection{Otwarcie pliku wejściowe- go}

Aby rozpocząć działanie programu należy nacisnąć przycisk „Otwórz plik (*.dia)” i wskazać w wyświetlonym oknie otwarcia pliku plik wejściowy, z którego mają być tworzone przebiegi danych diagnostycznych. Może zostać wybrany jedynie plik z rozszerzeniem „dia”.

\subsection{Wybór danych diagnostyeznych}

Po poprawnym otwarciu pliku wejściowego pojawia się okno wyboru danych diagnostycznych, których przebiegi mają być narysowane na wykresie. Okno „Wybór zmiennych” składa się z listy danych (pobranej z pliku wejściowego) oraz przycisków „Akceptuj” i „Anuluj”. Można wybrać do 20 pozycji. Do „przewijania” listy danych służy pasek umieszczony po prawej stronie okna „Wybór zmiennych”. Nad przyciskami „Akceptuj” i „Anuluj” wyświetlana jest informacja o liczbie danych jaką jeszcze można wybrać. Natomiast w oknie głównym programu przycisk „Otwórz plik (*.dia)” staje się nieaktywny, a stają się widoczne elementy umożliwiające zmianę atrybutów narysowanego wykresu oraz elementy umożliwiające zapis narysowanego wykresu do pliku.

Jeżeli program nie zostanie zamknięty, to przy wyborze kolejnego pliku do analizy pamiętane są pozycje zaznaczone w oknie „Wybór zmiennych”.

\subsection{Konfiguracja „Offsetu” $i$ „Mnożnika” serii}

Po wybraniu do 20 danych w oknie „Wybór zmiennych” i naciśnięciu przycisku „Akceptuj” w jego miejsce pojawia się okno wyboru „Offsetu” (liczba naturalna z zakresu od 0 do 100, wartość domyślna: 0) i „Mnożnika” (liczba naturalna z zakresu od 1 do 100 , wartość domyślna: 1) dla poszczególnych serii.

Wprowadzenie „Offsetu” i „Mnożnika” umożliwia „rozsunięcie” poszczególnych serii na wykresie, co ma istotne znaczenie przy analizie przebiegów binarnych.

\subsection{Tworzenie wykresu}

Po naciśnięciu przycisku „Akceptuj” w oknie konfiguracji „Offsetu” i „Mnożnika” dla poszczególnych serii, program rozpoczyna tworzenie wykresu. Narysowanie punktu danej serii przebiega następująco:

- jako współrzędna X punktu wykresu przyjmowana jest wartość próby odebrania ramek

- $\quad$ z pliku wejściowego pobierana jest wartość danej diagnostycznej stowarzyszonej z daną serią

- $\quad$ wartość ta mnożona jest przez „Mnożnik” danej serii

- po dodaniu do wyniku powyższej operacji wartości „Offsetu” danej serii otrzymywana jest współrzędna Y punktu wykresu, czyli: współrzędna Y punktu wykresu $=($ wartość z pliku * „Mnożnik” $)+$ „Offset”

$\mathrm{Na}$ dole okna głównego umieszczono pasek postępu tworzenia wykresu. Po zakończeniu przetwarzania przez program pliku wejściowego pole wykresu jest odświeżane.

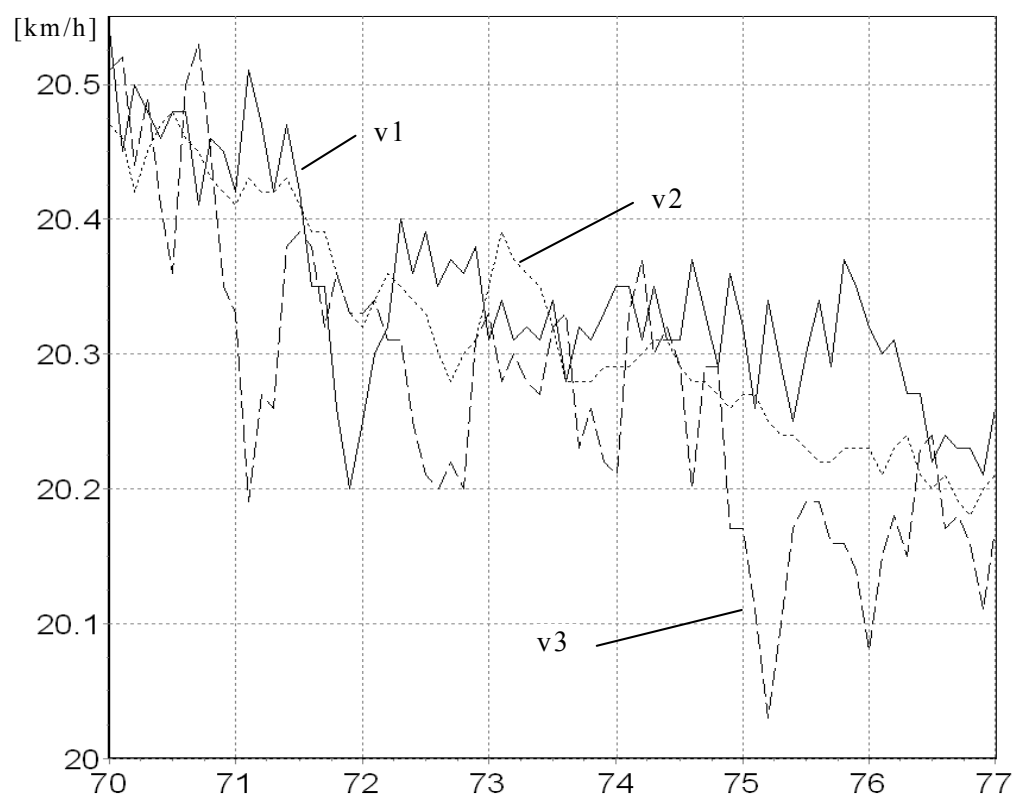

Rys. 8. Przykładowy wykres otrzymany przy użyciu programu „WYKRESY” 
Na rysunku 8 przedstawiono wykres stworzony w oparciu o plik uzyskany podczas jazdy zmodernizowaną lokomotywą ST44. Jako przykład wybrano przebiegi prędkości osi pierwszego wózka lokomotywy $\left(v_{1}, v_{2} i v_{3}\right)$.

\subsection{Konfiguracja narysowanego wykresu}

Poniżej przycisku „Otwórz plik (*.dia)” umieszczono elementy służące do konfiguracji poszczególnych serii oraz osi wykresu (rys. 7).

Można zmienić następujące parametry poszczególnych serii:

- ustalić czy dana seria ma być widoczna czy też niewidoczna na wykresie

- zmienić grubość linii (zakres: od 1 do 3, domyślnie: 2)

- zmienić rodzaj linii (jedynie, gdy grubość linii równa jest 1)

- zmienić kolor linii.

Można również:

- ustalić (po wyłączeniu opcji „Auto”) minimum, maksimum i podziałkę osi wykresu

- powiększyć wybrany obszar wykresu: za pomoca lewego klawisza myszy należy zaznaczyć wybrany fragment od lewego górnego do prawego dolnego narożnika

- ,przesunąć” wykres za pomocą prawego klawisza myszy.

Powrót do pierwotnego wyglądu wykresu następuje po zaznaczeniu dowolnego obszaru wykresu od prawego dolnego do lewego górnego narożnika.

Po naciśnięciu dowolnego klawisza myszy na wybranej serii wyświetlane jest okno zawierające następujące informacje na temat „klikniętego" punktu:
- współrzędna X

- współrzędna Y

- $\quad$ wartość (oryginalna, pobrana z pliku wejściowego)

- „Offset” i „Mnożnik” serii.

\section{Podsumowanie i wnioski}

Programy „DIAGNOSTYKA” i „WYKRESY” znacznie ułatwiły i przyspieszyły proces wdrażania mikroprocesorowych systemów sterowania na pojazdach szynowych. Dzięki nim możliwe było wszechstronne prześledzenie i optymalizacja działania systemu sterowania jak też sterowanego układu. Analiza taka pozwala wykryć niewłaściwe działanie układu, będącego przedmiotem sterowania jak też ewentualne błędy przyjętych algorytmów i oprogramowania.

Programy te (po niewielkich modyfikacjach kodu źródłowego programu „DIAGNOSTYKA”) można zastosować do wizualizacji i archiwizacji danych diagnostycznych przesyłanych za pośrednictwem interfejsu RS232 z dowolnego sterownika PLC wyposażonego $\mathrm{w}$ port szeregowy, przystosowany do transmisji danych podczas normalnej pracy sterownika.

\section{Literatura}

[1] Daniluk A.: RS 232C. Praktyczne programowanie. Od Pascala i $\mathrm{C}++$ do Delphi $i$ Buildera. Wydawnictwo Helion, 2001.

[2] Kasprzyk J.: Programowanie sterowników przemystowych. WNT, Warszawa 2006. 